PRZEGLĄD NAUK HISTORYCZNYCH 2020, R. XIX, NR 1

http://dx.doi.org/10.18778/1644-857X.19.01.05

\title{
Między konwencją a nowoczesnością - z dziejów małżeństwa Tomasza i Katii Mannów
}

Streszczenie. Artykuł prezentuje oryginalny na tle epoki charakter małżeństwa Tomasza i Katii Mannów. Opierając się na pamiętnikach i korespondencji członków rodziny pisarza, ukazano konwencjonalne oraz nowoczesne elementy ich związku, zarówno w kontekście relacji osobistych, jak i przez pryzmat modelu wychowania potomstwa.

Konstrukcja artykułu ma charakter chronologiczno-problemowy. W pierwszej części rozważań przedstawiono młodzieńczy bagaż doświadczeń Tomasza Manna i Katii Pringsheim do momentu zawarcia przez nich związku małżeńskiego (1904). W drugiej części przeanalizowano proces formowania się relacji małżeńsko-rodzicielskich wspomnianej pary (1904-1914). Trzecia część prezentacji przedstawia ewolucję pozycji w związku Katii Mann (1914-1919). W ostatniej części artykułu dokonano zbiorczej analizy charakteru małżeńskich relacji Tomasza i Katii Mannów $z$ uwypukleniem tradycyjnych i nowoczesnych cech ich małżeństwa.

Słowa kluczowe: Mannowie, Tomasz Mann, Katia Mann, małżeństwo w Niemczech w XX wieku.

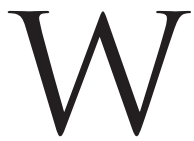

historii niemieckiej kultury rodzina Mannów zajmuje miejsce szczególne. Już w końcu lat trzydziestych XX w. w publicystyce zachodniej pojawiło się określenie „amazing family", odnoszace się do roli odgrywanej przez nią w reprezentowaniu idei „innych” (antynazistowskich) Niemiec ${ }^{1}$. Po drugiej

* Wydział Filozoficzno-Historyczny, Instytut Historii, Katedra Historii Powszechnej Najnowszej, e-mail: katarzyna.jedynakiewicz@uni.lodz.pl

1 Autorem określenia był brytyjski polityk i pisarz Harold Nicholson. Sformułowanie pochodzi $z$ recenzji anglojęzycznej edycji książki Eryki Mann School for Barbarians, wydanej w 1938 r. 
wojnie światowej, na fali niesłabnącego zainteresowania życiem Tomasza Manna i jego bliskich, do obiegu weszło sformułowanie „niemieccy Windsorowie”. Kanwę określenia stanowiła nie tylko wielopokoleniowa struktura rodu, lecz także wpływ Mannów na poprawę wizerunku Niemiec po upadku nazizmu ${ }^{2}$. O fenomenie rodziny świadczą zarówno książki na jej temat, jak i ekranizacje dzieł samego Tomasza Manna. Przykładem udanego połączenia obu typów narracji był choćby film i ksiażka Heinricha Breloera z 2001 r. ${ }^{3}$ Także w ostatnich latach, najczęściej w związku z rocznicami urodzin i śmierci pisarza, na rynku ukazuja się nowe pozycje źródłowe ${ }^{4}$ i monografie ${ }^{5}$ ukazujące losy członków rodziny autora Czarodziejskiej góry.

Spośród tematów poruszanych przez współczesnych pisarzy opisujących Mannów dominują bądź biografie poszczególnych reprezentantów rodu, bądź studia poświęcone całej rodzinie noblisty ${ }^{6}$. $\mathrm{Na}$ tle wspomnianych wątków badawczych zdecydowanie słabiej wypada refleksja nad historia małżeństwa Tomasza i Katii Mannów, trwającego ponad 50 lat, aż do śmierci pisarza w $1955 \mathrm{r}$. Tymczasem związek wspomnianej pary zasługuje na odrębną analizę historyczna, jako przykład oryginalnego połączenia konwencji $z$ nowoczesnością, tradycyjnego podziału ról i partnerskiego modelu relacji.

${ }^{2}$ Metafora zawdzięcza swe powstanie niemieckiemu krytykowi literackiemu Marcelemu Reich-Ranickiemu.

${ }^{3}$ Por. H. Breloer, Unterwegs zur Familie Mann. Begegnungen, Gespräche, Interviews, Frankfurt am Main 2001. Książka stanowi zapis literacki rozmów autora z uczestnikami filmu. Obraz nosił tytuł Die Manns. Ein Jahrhundertroman.

${ }^{4}$ Wśród pozycji źródłowych na uwage zasługuje nowa, poszerzona edycja listów Katii Mann oraz zbiór korespondencji rodziny Mannów - K. Mann, "Liebes Rehherz". Briefe an Thomas Mann 1920-1950. Erweiterte Neuausgabe, hrsg. I. Jens, D. Heißerer, 2. Ausgabe, Würzburg 2016; Die Briefe der Manns. Ein Familienporträt, hrsg. T. Lahme, H. Pils, K. Klein, Frankfurt am Main 2016.

5 T. Lahme, Die Manns. Geschichte einer Familie, Frankfurt am Main 2015; M. Flügge, Das Jahrhundert der Manns, Berlin 2015.

${ }^{6}$ Do klasycznych monografii na temat rodziny Mannów należą prace Marcela Reich-Ranickiego i Marianne Krüll - M. Reich-Ranicki, Thomas Mann und die Seinen, Frankfurt am Main 1990; M. Krü11, Im Netz der Zauberer. Eine andere Geschichte der Familie Mann, Frankfurt am Main 1993. Poszerzony obraz przedstawicieli rodziny Mannów daja biografie babki i matki żony pisarza, Katii Mann - H. Brandt, „Die Menschenrechte haben kein Geschlecht”. Die Lebensgeschichte der Hedwig Dohm, Weinheim-Basel 1995; I. i W. Jens, Katias Mutter. Das auerordentliche Leben der Hedwig Pringsheim, Reinbek bei Hamburg 2007 (wydanie w twardej oprawie w 2005 r.). 
Artykuł przedstawia genezę małżeństwa Tomasza i Katii Mannów oraz proces ewolucji ich wzajemnych stosunków w latach 19051919, tj. od ślubu do urodzin najmłodszego z dzieci pary, Michaela. Ograniczony chronologicznie charakter rozważań ma swoje uzasadnienie. To właśnie we wspomnianym okresie relacje małżeńskie pisarza uległy największym zmianom, wynikającym zarówno z czynników obiektywnych (wzrost statusu i poziomu zamożności, narodziny sześciorga dzieci), jak i subiektywnych (ewolucja osobowości Katii Mann, skutkująca wzrostem pozycji w małżeństwie). Kolejne lata życia związku przyniosa jedynie wzmocnienie opisanej tendencji, widoczne szczególnie w okresie emigracyjnej tułaczki autora Czarodziejskiej góry po 30 stycznia 1933 r.

$Z$ uwagi na biograficzny kontekst analizy autorka uznała za stosowne włączyć do wywodu obszerne wprowadzenie. Prezentuje ono bagaż młodzieńczych doświadczeń Tomasza i Katii przed zawarciem związku małżeńskiego. $Z$ kolei w celu oddania specyfiki relacji małżonków zrekonstruowano najważniejsze elementy stylu wychowawczego obojga wobec potomstwa, jednak bez ambicji przeprowadzenia szczegółowej analizy problemu.

Artykuł ma strukturę chronologiczno-problemowa. W pierwszej części rozważań przedstawiono proces formowania się relacji małżeńskiej Tomasza i Katii Mannów w latach 1905-1914. W drugiej części ukazano ewolucję pozycji w związu żony pisarza w okresie pierwszej wojny światowej. W ostatniej części artykułu dokonano zbiorczej analizy relacji Tomasza i Katii Mannów, uwypuklając zarówno tradycyjne, jak i niekonwencjonalne cechy charakteru ich małżeństwa.

Źródłową bazę rozważań stanowią dzienniki, wspomnienia i wydana drukiem korespondencja autora Czarodziejskiej góry i jego żony. Istotną rolę $\mathrm{w}$ analizie zagadnienia odegrały także pamiętniki trojga dzieci tej pary: Klausa ${ }^{7}$, Gola $^{8}$ i Moniki ${ }^{9}$. Wykorzystana $\mathrm{w}$ tekście literatura przedmiotu ma charakter wybiórczy. Jej trzon stanowią wydane w XXI w. prace niemieckich znawców życia i twórczości rodziny Mannów.

7 K. Mann, Kind dieser Zeit, Reinbek bei Hamburg 1967; id e m, Punkt zwrotny, Warszawa 1993.

${ }^{8}$ G. Man n, Erinnerungen und Gedanken. Eine Jugend in Deutschland, Frankfurt am Main 1986.

9 M. M a n n, Vergangenes und Gegenwärtiges. Einnerungen, Reinbek bei Hamburg 2001. 


\section{Młodzieńczy bagaż doświadczeń Tomasza Manna (ur. 1875)}

Rodzina po mieczu Tomasza Manna wywodziła się wprawdzie $z$ Meklemburgii, lecz od 1775 r. związała swe losy z Wolnym Miastem Lubeka. Mieszczański status społeczny i zamożność zawdzięczała handlowi zbożem. Ojciec pisarza, Tomasz Mann senior, cieszył się poważaniem miejskiej społeczności, czego dowodem była dożywotnia godność członka Senatu Lubeki. Zmarł na chorobę nowotworową w 1891 r., osierocajac piątkę dzieci, w tym dwoje małoletnich ${ }^{10}$. Będąc świadomym braku zainteresowania rozwojem firmy dwóch najstarszych synów, wydał w testamencie dyspozycję likwidacji przedsiębiorstwa. Wdowa i potomstwo otrzymali skromną rentę ${ }^{11}$. W momencie śmierci ojca Tomasz Mann junior miał 16 lat $^{12}$.

Mieszczańskie korzenie miała również matka noblisty, Julia da Silva Bruhns. Urodziła się w Brazylii, jako dziecko niemieckiego kupca i Portugalki. Po śmierci żony wdowiec osiadł z córką w Lubece. Po wyjściu za mąż za Tomasza Manna seniora Julia nie odnalazła się w protestancko-kupieckiej atmosferze miasta. Swe życie wypełniała muzyka i sztuka, a humanistyczne zainteresowania przekazała w genach dwóm starszym synom oraz córce Carli ${ }^{13}$.

Późniejsze wybory życiowe Tomasza Manna juniora świadczyły o wpływie na jego rozwój obojga rodziców. Wprawdzie za młodu nie przejawiał chęci naśladowania rodzinnych wzorców mieszczańskich, odziedziczył jednak wiele cech po swym ojcu: pracowitość, obowiązkowość, uporządkowanie i odpowiedzialność za rodzinę ${ }^{14}$. $Z$ bratem Henrykiem, zdecydowanie mniej przywiazanym do tradycji rodu, dzielił wprawdzie literackie pasje, ale nie styl życia ${ }^{15}$.

Bardziej złożony wpływ na noblistę wywarła matka. W świetle wspomnień Katii Mann więzy jej teściowej z synami były zawsze

10 Tomasz Mann był drugim dzieckiem swych rodziców, urodzonym w $1875 \mathrm{r}$. Jego starszy brat Henryk urodził się w 1871 r., siostry Julia i Carla w latach (odpowiednio) 1877 i 1881, natomiast brat Viktor w 1890 r.

11 Spadek okazał się niewysoki, ponieważ pod koniec życia Tomasza seniora firma mocno podupadła.

${ }^{12}$ M. Flügge, op. cit., s. 15-18.

${ }^{13}$ H. Kurzke, Tomasz Mann. Życie jako dzieło sztuki, Warszawa 2005, s. 17. Carla Mann została aktorka.

${ }^{14}$ K. Man n, Moje nienapisane wspomnienia, Warszawa 2007, s. 31.

15 Henryk Mann przez całe dorosłe życie słynął z licznych miłostek, przywiazania do wystawnych posiłków i trunków. Por. M. Flügge, Heinrich Mann. Eine Biographie, Reinbek bei Hamburg 2006, s. 87 i n. 
bliskie ${ }^{16}$. W przypadku Tomasza można było mówić o fizycznym podobieństwie matki i żony (obie panie były brunetkami o ciemnych oczach). Przywiazanie pisarza do pierwszej z wymienionych nie oznaczało jednak bezwarunkowej akceptacji jej życiowych wyborów. Gdy po przeprowadzce Julii do Monachium (1893) nawiązała ona towarzyskie kontakty $z$ miejscowa bohema, syn nie był zachwycony jej zbyt "frywolnym” otoczeniem ${ }^{17}$.

Niezależnie od dystansu Tomasza wobec znajomych matki, to właśnie tej ostatniej zawdzięczał wybór Monachium jako przyszłego miejsca osiedlenia. O decyzji przesadziła ostatecznie nie tylko artystyczna renoma miasta, lecz także religijna atmosfera południa Niemiec. Mimo protestanckiego wychowania przyszłego noblistę pociagały duchowe tradycje rzymskiego katolicyzmu ${ }^{18}$. Zdecydowanie mniej łączyć będzie pisarza $z$ postawą obyczajowego rozluźnienia miejscowej awangardy artystycznej. Wprawdzie w poczatkach aktywności literackiej uczestniczył w karnawałowych zabawach w monachijskim Schwabingu, ale zarzucił ten zwyczaj po założeniu rodziny. W jego mieszkaniach, a później domach dominowali co prawda przedstawiciele świata kultury, ale były to osoby nieafiszujace się łamaniem obyczajowych konwencji.

Sam Tomasz Mann był we wspomnianym gronie postacia niewolna od paradoksów. Mimo awersji do gimnazjalnego wykształcenia imponował rozległa wiedza akademicką ${ }^{19}$. Jako "genetyczny” konserwatysta szanował tradycje, społeczna hierarchię i instytucje państwa, odrzucał jednak cenzurę, zwłaszcza w sferze kultury ${ }^{20}$. W politycznych zapatrywaniach ewoluował od nacjonalizmu, przez akceptację demokracji parlamentarnej, po lewicowo-liberalne sympatie w ostatniej dekadzie życia.

Ukrytą częścią osobowości Manna były jego homoerotyczne fascynacje ${ }^{21}$. Szczupli, wysportowani młodzieńcy oraz „anielscy” chłopcy wzbudzali w nim emocje większe niż najbardziej urodziwe kobiety ${ }^{22}$. Nietypowe w wyborach przyszłego noblisty były nie

16 Ibidem, s. 28.

17 H. Kurzke, op. cit., s. 17.

18 Ibidem, s. 90-91.

19 Inaczej niż Henryk, Tomasz Mann nie ukończył szkoły średniej. W toku nauki kilkakrotnie powtarzał klasy. Por. ibidem, s. 26.

${ }^{20}$ Ibidem, s. 181-182.

${ }^{21}$ Ibidem, s. 35 i n.

${ }^{22}$ O preferencjach seksualnych Tomasza Manna wiele mówią jego dzienniki. 
tylko preferencje seksualne, lecz także ich świadome wyparcie z życia realnego. W opublikowanym w 1925 r. eseju O małżeństwie określał homoseksualizm jako zjawisko „nieodpowiedzialne społecznie"23. W swych poglądach odróżniał homoseksualizm i homoerotyzm - ten drugi uważał za dozwolony, bo pozostający w świecie fantazji i wartości estetycznych ${ }^{24}$.

W świetle ustaleń znawców życia Tomasza Manna nie ma dowodów na jego intymne kontakty $z$ mężczyznami. Nie wiemy, czy przed ślubem $z$ Katia Pringsheim przeszedł heteroseksualna inicjację seksualna. Mimo namów Henryka nigdy nie korzystał z usług prostytutek i przejawiał odrazę do seksu za pieniądze. Być może stracił „niewinność” w przelotnej relacji ze służącą ${ }^{25}$. Jedno jest pewne - porzucając w 1904 r. „nieład uczuciowy”, z żelazna determinacja przestrzegać będzie etosu dobrego męża i ojca, sublimując ukryte pragnienia w opisie swych bohaterów literackich ${ }^{26}$.

\section{Młodzieńczy bagaż doświadczeń Katii Mann (ur. 1883)}

Przodkowie Katii Mann po mieczu i kądzieli wywodzili się z żydowskich rodzin ze Śląska ${ }^{27}$. Rodzina ojca Katii, Alfreda Pringsheima, osiągnęła milionowy majątek dzięki interesom w branży kolejowej. On sam wybrał droge kariery akademickiej na uniwersytecie w Monachium w zakresie matematyki. Wysoka stope materialna zawdzięczał nie tyle pracy zawodowej (przez wiele lat wykładał pro bono jako tzw. Privatdozent), ile imponujaco wysokim odsetkom od rodzinnego kapitału. Obok naukowych pasji był $z$ zamiłowania muzykiem, kolekcjonerem dzieł sztuki i mecenasem twórczości Ryszarda Wagnera. Swojej żonie i dzieciom zbudował imponujacy wielkością pałac w centrum miasta przy Arcisstrasse ${ }^{28}$.

W przypadku matki Katii, Hedwig Pringsheim, jej korzenie miały wprawdzie również charakter mieszczański, ale $z$ inteligenckim

${ }^{23}$ T. Lahme, op. cit., s. 38. Wspomniana ocena nie miała wprawdzie wpływu na relacje $z$ homoseksualnym synem Klausem, ale implikowała dystans wobec jego doraźnych partnerów seksualnych.

${ }^{24}$ M. Flügge, Das Jahrhundert..., s. 107-108. Przykłady tak rozumianego homoerotyzmu pisarz odnajdywał w przyjaźniach literackich doby romantyzmu.

${ }^{25}$ H. Kurzke, op. cit., s. 51, 66.

${ }^{26}$ M. Flügge, Das Jahrhundert..., s. 110.

27 Zarówno Pringsheimowie, jak i Dohmowie po opuszczeniu Śląska osiedli w Berlinie. Por. K. J üngling, B. Roß b e ck, Katia Mann. Die Frau des Zauberers. Biografie, München 2003, s. 9, 26.

${ }^{28}$ Ibidem, s. 26-29, 35. 
zabarwieniem. Ojciec Hedwig, Ernst Dohm był dziennikarzem i pisarzem, sympatykiem rewolucji 1848 r. w Prusach. Jej matka, Hedwig Dohm, wspierana przez męża w swej pasji literackiej, należała do pionierek pisarstwa kobiecego w Niemczech i sympatyczek ruchu na rzecz praw kobiet ${ }^{29}$. Wprawdzie sama Hedwig Pringsheim nie poszła w ślady matki, ale po wyjściu za mąż nie zarzuciła zainteresowań literatura, muzyka i sztuka ${ }^{30}$. Jej błyskotliwa inteligencja i uroda przyciagały kulturalna elitę Monachium do wydawanych co niedziela w domu przy Arcisstrasse podwieczorków ${ }^{31}$.

Podobnie jak Tomasz Mann, Katia Pringsheim miała czworo rodzeństwa - Eryka (1879), Petera (1881) i Heinza (1882) oraz bliźniaczego brata Klausa (1883). Dorastała w warunkach komfortu materialnego, w trzypiętrowym pałacu, wyposażonym w centralne ogrzewanie i łazienki na każdym piętrze ${ }^{32}$. Jako jedyna córka była oczkiem w głowie rodziców i rodzeństwa. Nigdy nie zaznała frustracji z powodu przynależności do „gorszej płci” - wręcz przeciwnie, podobnie jak bracia uprawiała sporty, jeździła na rowerze i uczestniczyła w chłopięcych zabawach ${ }^{33}$. Mali Pringsheimowie zwracali się do rodziców w drugiej osobie i mieli prawo wyrażania własnego $z_{\text {dania }}{ }^{34}$. O nowoczesności wychowania Katii świadczyła również edukacja dziewczynki. Podobnie jak bracia odebrała wykształcenie w zakresie gimnazjum klasycznego, tyle że w trybie eksternistycznym $^{35}$. Po uzyskaniu pozwolenia ministra odpowiedzialnego za edukację w Bawarii (Kultusminister) zdała maturę jako jedna

${ }^{29}$ K. Mann, Moje..., s. 13-14. Wbrew wspomnieniom Katii, jej babka nie była „zaciekłą feministka”, jeśli przez to określenie rozumieć aktywność w ruchu kobiecym. Swe feministyczne poglądy prezentowała w formie twórczości literackiej. Jej powieści, dziś anachroniczne, były bardzo popularne w czasach wilhelmińskich. Por. K. Jüngling, B. Roß beck, op. cit., s. 18-21.

${ }^{30}$ We wczesnej młodości Hedwig występowała jako aktorka na prowincjonalnych scenach Niemiec. Nie odnosząc sukcesów jako aktorka, bez większych wahań przyjęła ofertę matrymonialną Alfreda Pringsheima. Por. I. i W. J en s, op. cit., s. 42-49, 106.

${ }^{31}$ I. i W. Jens, op. cit., s. 28, K. Jüngling, B. Roß beck, op. cit., s. 33.

32 K. Jüngling, B. Roß beck, op. cit., s. 35-36. Dom Pringsheimów wybudowany został w 1890 r. w centralnej części Monachium. Jego powierzchnia wynosiła 1500 metrów kwadratowych.

${ }^{33}$ Ibidem, s. 41-42.

${ }^{34}$ I. i W. Jen s, Pani Tomaszowa Mann, Warszawa 2006, s. 21.

${ }^{35}$ K. Mann, Moje..., s. 10; K. Jüngling, B. Roßbeck, op. cit., s. 43-44. W 1893 r. w Monachium nie działało jeszcze żadne gimnazjum dla dziewcząt. W powyższym stanie rzeczy państwo Pringsheim opłacali prywatnych nauczycieli, realizujących $z$ Katia pełen program gimnazjalny. 
z pierwszych abiturientek w Monachium, $z$ ocenami wyższymi niż brat Klaus ${ }^{36}$. Najlepsze noty uzyskała $z$ łaciny, greki i francuskiego (angielski poznała niezależnie od programu szkolnego). Paradoksem jest to, że przyszła żona Tomasza Manna najsłabiej wypadła $z$ języka niemieckiego. Ocena „wystarczajaca” $z$ tego przedmiotu była ewidentna niesprawiedliwością, zważywszy oczytanie Katii i znakomity styl jej późniejszej korespondencji.

Ukoronowanie edukacji przyszłej żony Tomasza Manna stanowić miały uniwersyteckie studia w zakresie matematyki i fizyki. Trudno określić, na ile był to pomysł jej feministycznej babki, na ile zaś wybór samej Katii. Wydaje się, że przynajmniej wybór kierunku studiów wynikał bardziej z preferencji Alfreda Pringsheima niż $z$ zainteresowań jego córki ${ }^{37}$. O umiarkowanej motywacji do studiów Katii świadczyć będzie także decyzja o przerwaniu edukacji po oświadczynach Tomasza Manna. Nie jest wykluczone, że to perspektywa pracy dyplomowej przyśpieszyła zgodę Katii na szybką datę ślubu ${ }^{38}$. Nie zmienia to faktu, że przyszła żona pisarza była $\mathrm{w}$ zakresie edukacji kobietą nietypowa, jedną $z$ pierwszych adeptek uniwersytetu $\mathrm{w}$ Monachium, dopuszczona do pełnych praw akademickich ${ }^{39}$.

Więzy emocjonalne łączyły Katię $z$ obojgiem rodziców, ale bliskie relacje miała przede wszystkim $z$ matką. Ojciec Alfred był wprawdzie autorytetem intelektualnym ${ }^{40}$, ale nie moralnym. Zarówno Hedwig, jak i Katia wiedziały o „przyjaciółce” głowy rodu, śpiewaczce operowej. Ta ostatnia bywała nawet na herbatkach i kolacjach przy Arcisstrasse. Hedwig co prawda wybrała postawę wyrozumiałości wobec romansu męża, ale po latach określała rywalkę jako osobę, która „uczyniła jej wiele złego" ${ }^{41}$. Także Katia, pozornie pogodzona $z$ postępowaniem ojca, nie zapomniała dziecięcych obaw o porzu-

${ }^{36}$ K. Jüngling, B. Roß beck, op. cit., s. 44-45.

${ }^{37}$ K. Mann, Moje..., s. 11. W ciągu pierwszych lat studiów Katia uczęszczała także na zajęcia $z$ języka rosyjskiego.

${ }^{38}$ Teza Hermanna Kurzkego, jakoby Katia planowała napisanie doktoratu, nie ma pokrycia w żadnym źródle. Por. H. Kurzke, op. cit., s. 151.

${ }^{39} \mathrm{~W}$ roku rozpoczęcia studiów przez Katię (1901) na uniwersytecie w Monachium studiowało 38 kobiet. Do roku akademickiego 1903/1904 miały one jedynie status „wolnych słuchaczek”: nie korzystały ze zniżek akademickich, miały ograniczony (zależny od woli wykładowcy) wstęp na zajęcia, nie mogły korzystać z biblioteki uniwersyteckiej. Por. K. J üngling, B. Roß b e ck, op. cit., s. 46-49.

${ }^{40}$ K. Mann, Moje..., s. 11-12.

${ }^{41}$ G. Mann, op. cit., s. 219. 
cenie przez niego rodziny. Czy doświadczenia $z$ okresu dojrzewania nauczyły ja „życia ze skandalami”42? Równie dobrze można założyć, że $z$ lat tych wyniosła sceptycyzm co do charakteru mężczyzn ${ }^{43}$ i przeciwstawną tej ocenie potrzebę życia u boku odpowiedzialnego partnera.

W porównaniu $z$ wyrosłym w protestantyzmie Tomaszem Mannem tożsamość religijna Katii była bardziej złożona. Rodzina matki przyjęła chrześcijaństwo w obrządku ewangelickim w początkach XIX w. Konfesja Alfreda Pringsheima pozostaje niejasna - zapewne został ochrzczony, jednak jeszcze w dokumentach uniwersyteckich wpisał jako wyznanie "mojżeszowe”. Według wspomnień współczesnych był agnostykiem odległym od jakiejkolwiek religii. Ślub rodziców Katii miał charakter świecki, ale swe potomstwo ochrzcili w obrządku luterańskim ${ }^{44}$. Mali Pringsheimowie wiedzieli o semickich korzeniach rodziców, ale żydowskość utożsamiali wyłącznie $z$ religią ${ }^{45}$. Zarówno Katii, jak i jej matce zdarzały się w korespondencji passusy antysemickie, szczególnie w odniesieniu do tzw. Ostjuden ${ }^{46}$.

\section{Geneza małżeństwa Tomasza Manna i Katii Pringsheim (1904-1905)}

Decydującym dla przyszłego małżeństwa Mannów był rok 1904. Od czasu publikacji debiutanckiej powieści Buddenbrookowie trzy lata wcześniej sytuacja materialna pisarza była stabilna, a dojrzały wiek i potrzeba życiowej stabilizacji uzasadniały podjęcie zabiegów matrymonialnych.

W świetle wspomnień Katii Tomasz Mann widywał ja wprawdzie w teatrach Monachium, ale impulsem do nawiązania kontaktu był incydent $\mathrm{w}$ tramwaju. Jako pasażer był świadkiem sporu panny Pringsheim $z$ kontrolerem biletów, zakończonego wyskoczeniem

\footnotetext{
42 Por. I. i W. J en s, Pani Tomaszowa..., s. 24-25.

${ }^{43}$ Doświadczeń mężowskiej niewierności zaznała nie tylko matka Katii, lecz także babka, Hedwig Dohm. Por. I. i W. J ens, Katias Mutter..., s. 17-19.

${ }^{44}$ K. Jüngling, B. Roß beck, op. cit., s. 9-11.

45 I. i W. Jen s, Pani Tomaszowa..., s. 26-27.

${ }^{46}$ K. Mann, „Liebes...”, s. 37, 68; I. i W. Jen s, Katias Mutter..., s. 96. Gdy w 1914 r. Henryk Mann poślubił czeska Żydówkę Mimi Kanova, Hedwig Pringsheim bardzo krytycznie oceniała ten wybór. Jej zastrzeżenia budziła np. kwestia wyznania ewentualnego potomstwa pisarza. Jako w pełni zasymilowana niemiecka Żydówka była przeciwna podkreślaniu przez Mimi swej żydowskiej tożsamości. Por. M. Flüg ge, Heinrich Mann..., s. 45-46.
} 
dziewczyny $z$ jadącego pojazdu. Według Katii przyszły mąż był tak zafascynowany temperamentem panny, że postanowił poznać ją bliżej ${ }^{47}$.

W korespondencji Tomasza Manna $z$ Henrykiem Katia Pringsheim pojawia się w lutym 1904 r. W kolejnych tygodniach pisarz relacjonował bratu swe wizyty $\mathrm{w}$ domu panny przy Arcisstrasse. Jego poważne zamiary zyskały szybko poparcie Hedwig Pringsheim, dobrze orientujaccej się w pozycji literackiej kawalera ${ }^{48}$. Mniej entuzjastyczny był ojciec Katii, niemajacy początkowo przekonania do profesji Tomasza Manna. Dopiero informacje o powodzeniu czytelniczym pisarza oraz wagnerowskie zainteresowania tego ostatniego przełamały lody.

Mimo że przyszły noblista stał się szybko regularnym gościem przy Arcisstrasse, panna Pringsheim zdawała się nie śpieszyć do rychłych zaręczyn. Po latach twierdziła, że nie chciała jeszcze porzucać beztroskiej egzystencji rozpieszczonej córki i towarzystwa znajomych ze studiów. Powodem wahań mogła też być niska samoocena Katii. Mimo ewidentnej urody (delikatne rysy twarzy, wielkie oczy, perłowej barwy cera, wijące się włosy) nie miała świadomości bycia atrakcyjną w oczach mężczyzn. Za piękną uważała wyłącznie matke, a w opinii tej umacniała ja babka, Hedwig Dohm ${ }^{49}$. Choć rodzice traktowali córkę jak równa synom, ona sama uważała w dzieciństwie swa płeć za „błąd naturalny”. Dopiero w wieku dorastania zaczęła przejawiać cechy typowe dla tradycyjnych wzorców zachowania ${ }^{50}$. W przekonaniu o wartości małżeństwa umacniała ja matka, niepodzielająca opinii o potrzebie posiadania przez kobietę wyższego wykształcenia ${ }^{51}$. Na czele swych priorytetów stawiała już wówczas nie tytuł naukowy, lecz macierzyństwo ${ }^{52}$.

${ }^{47}$ K. Mann, Moje..., s. 18-20. Planując wysiąść na najbliższym przystanku, Katia podobno wyrzuciła bilet. Istnieje możliwość, że po prostu jechała „na gapę”.

48 Ibidem, s. 21-22.

49 Ibidem, s. 15. Babka Katii mówiła podobno: „Ach, matce to ty nigdy nie dorównasz".

50 I. i W. J en s, Pani Tomaszowa..., s. 20. Z korespondencji Hedwig Pringsheim wynika, że jej córka w okresie dojrzewania stała się małą pedantką.

${ }^{51}$ K. Mann, Moje..., s. 24. Dowodem na utożsamianie się Hedwig Pringsheim $z$ tradycyjnym wzorcem powinności kobiet była jej krytyczna postawa wobec synowych. Gdy Heinz i Klaus poślubili artystki (pierwsza była malarka, druga tancerka teatralna), nie utrzymywała kontaktów z wybrankami synów. Por. I. i W. Jens, Katias Mutter..., s. 180.

${ }^{52}$ Pod koniec życia Katia miała mówić, że wyszła za mąż „tylko dlatego, aby mieć dzieci”. Por. G. Ma n n, op. cit., s. 19. 
Motywy wyboru Katii na żonę przez Tomasza Manna były złożone. Bezdyskusyjnym atutem panny były bogactwo oraz ranga społeczna jej rodziców. Pisarz cenił także kulturalne aspiracje i kontakty Pringsheimów. Mając świadomość niższego statusu materialnego, widział w swej kandydaturze równoważace ów mankament atuty: dobre, chrześcijańskie pochodzenie oraz potwierdzony sukcesem wydawniczym talent literacki. Semickie korzenie Katii bagatelizował, podkreślając, że w jej rodzinie „nie ma na wskroś żydostwa”. Przez to ostatnie rozumiał nie tylko chrześcijańska tożsamość wybranki, lecz także związki Pringsheimów z niemiecką kulturą. Warto podkreślić, że w późniejszych latach definiował się wręcz jako filosemita, doceniajacy wkład Żydow w „europejski dorobek kulturalny". W liście do Henryka rysował wizję związku dwóch wybitnych osobowości - „księcia” i „księżniczki”53.

W oczach Tomasza Manna osobistymi walorami jego wybranki były: uroda, osobowość oraz kulturalna ogłada. Korzystnie oceniał także różnicę wieku obojga (osiem lat). Mniej entuzjastycznie podchodził do wykształcenia panny - jej matury i rozpoczętych studiów $^{54}$. Swej niepewności nie ukrywał, choć neutralizował ją żartobliwa forma wypowiedzi. Czy w obawach autora Czarodziejskiej góry o „uczoność” Katii należy dopatrywać się antyfeminizmu ${ }^{55}$ ? Wprawdzie w młodości podzielał zdanie Fryderyka Nietzschego, że wyedukowane kobiety maja "problemy z kobiecościa”, jednak w przypadku Manna opinia ta wynikać mogła równie dobrze $z$ kompleksów na tle majątkowym. W przyszłości drażnić go będą nie tyle kobiety dobrze wykształcone, ile próbujące wpływać na jego twórczość ${ }^{56}$. W podobny sposób reagował na zachowania mężczyzn, nawet jeśli w ocenach tych nie stosował odniesień do spraw płci.

Nie znamy szczegółów zabiegów Tomasza Manna o rękę panny Pringsheim. Korespondencja obojga $z$ lata 1904 r., które Katia spędzała poza Monachium, się nie zachowała. Podobno listy pisarza były wręcz „natarczywe” uczuciowo, choć jednocześnie „piękne”57.

${ }^{53}$ Cyt. za: B. Jüngling, K. Roß beck, op. cit., s. 59. Filosemityzm Tomasza Manna miał swoje granice i nie dotyczył sfery ekonomicznej (ibidem, s. 73).

${ }^{54}$ Ibidem, s. 69.

${ }^{55}$ H. Kurzke, op. cit., s. 151.

56 W szczególny sposób tendencja ta wystapiła w relacjach Manna z Agnes Meyer, amerykańska entuzjastka dzieł pisarza i „dobra duszą" jego pobytu w Stanach Zjednoczonych. W tym przypadku niechęć podyktowana była także materialnym statusem Amerykanki, żony milionera Eugena Meyera. Por. M. Flügge, Das Jahrhundert..., s. 252-256.

${ }^{57}$ K. Mann, Moje..., s. 23. 
Czy Tomasz Mann obawiał się rywali do ręki dziewczyny? Jest to prawdopodobne, zważywszy na to, że Katią zainteresowany był także krytyk literacki Alfred Kerr. O wyborze przyszłego noblisty zadecydowała zapewne nie tylko panna Pringsheim, lecz także jej matka, negatywnie oceniająca twórczość Kerra ${ }^{58}$.

Ostatecznie w październiku 1904 r. wybranka Tomasza Manna przyjęła oświadczyny. Uroczystość zaślubin odbyła się w lutym 1905 r. w śródmiejskim urzędzie stanu cywilnego. Na świecką ceremonię nalegał ojciec Katii, a ona sama nie widziała we wspomnianym pomyśle nic zdrożnego ${ }^{59}$. Także Tomasz Mann nie nalegał na ślub w kościele, prosząc jedynie o możliwie skromny charakter uroczystości ${ }^{60}$. Zapewne $z$ jego inicjatywy posiłek weselny został ograniczony do obiadu na 15 osób w domu panny młodej. Sama Katia postawiła tylko jeden warunek - odmówiła włożenia na głowę welonu. Bliskim miała powiedzieć, że nie zamierza odgrywać w przyszłości roli „zwierzęcia ofiarnego"61.

\section{Małżeństwo Tomasza i Katii Mannów}

Podstawę stabilności małżeństwa Mannów stanowił dobrobyt materialny. Do 1914 r. komfortowe warunki egzystencji zapewniał - przynajmniej w części - Alfred Pringsheim. To on pokrywał koszty wynajęcia czteropokojowego, a po urodzeniu czwartego dziecka ośmiopokojowego mieszkania; on też umeblował pierwsze lokum młodej pary. Ukoronowaniem hojności ojca Katii było sfinansowanie budowy trzypiętrowego ( $z$ poddaszem) domu przy Poschingerstrasse. Willa położona była w nowo zasiedlonej dzielnicy Bogenhausen, a jej frontowe okna wychodziły na dolinę Izary ${ }^{62}$.

$\mathrm{Na}$ tle możliwości finansowych Alfreda Pringsheima dochody pisarza przedstawiały się dużo skromniej. Wprawdzie oprócz honorariów za kolejne książki coraz częściej dorabiał odczytami i publikowaniem drobnych tekstów literackich, jednak środki te

58 I. i W. Jens, Pani Tomaszowa..., s. 40.

59 K. Jüngling, B. Roß be ck, op. cit., s. 78.

60 Ibidem, s. 78-79. Zastrzeżenia do świeckiego ślubu miała matka pisarza, ale Hedwig Pringsheim udało się skłonić ją do zmiany stanowiska. „Argumentem perswazyjnym” były zapewne pieniądze rodziców panny młodej. To oni sfinansowali ślub i podróż poślubną młodej pary.

61 Ibidem, s. 79.

${ }^{62}$ K. Man n, Moje..., s. 27, 84 i n. Poczynając od drugiego lokum Mannów, we wszystkich ich mieszkaniach mieściły się minimum dwie łazienki. 
wystarczały jedynie na pokrywanie bieżących wydatków rodziny. Dopiero w 1909 r. przyszły noblista mógł pozwolić sobie na większą inwestycję - budowę letniej willi w podalpejskim Bad Tőlz ${ }^{63}$. W powyższym stanie rzeczy trudno się dziwić, że Tomasza Manna dręczyło skrywane poczucie niższości wobec Pringsheimów ${ }^{64}$. Irytację pogłębiały częste wizyty Alfreda i Hedwig oraz zwyczaj niedzielnych obiadów u teściów. Pisarza drażniła również zależność emocjonalna żony od Hedwig Pringsheim, pogłębiana rolą tej ostatniej w okresie połogów Katii ${ }^{65}$.

Podłoże niechęci Tomasza Manna leżało nie tylko w jego początkowych kompleksach, lecz także w postawie Pringsheimów. Nawet Katia przyznawała po latach, że $z$ rodzinnego domu wyniosła arogancję i zwyczaj „spoglądania na ludzi z góry”66. Wspomniane cechy przejawiali również jej rodzice oraz bracia, zwłaszcza bliźniaczy brat Klaus $^{67}$. Dla Tomasza Manna, majacego rozległa wiedzę $z$ zakresu kultury, denerwujaca była także przemąrzałość teścia, bazująca często na powierzchownej znajomości tematu ${ }^{68}$. Normalizację relacji przyniosła dopiero sława pisarza, pozwalająca na rozluźnienie finansowych więzi z Pringsheimami.

Mimo że Katia miała świadomość niechęci męża do jej rodziców, nie miało to trwałego wpływu na ich relacje. Ważniejszą rolę w budowaniu trwałości związku odgrywała jakość pożycia małżeńskiego. Wprawdzie w dziennikach Tomasza Manna można znaleźć wzmianki o okresowych „niedyspozycjach” pana domu i „wyrozumiałości" Katii, jednak pisarz utrzymywał z żoną regularne kontakty seksualne, a pożycie obojga trwało do wejścia Katii w okres klimakterium $^{69}$. Para dochowała się sześciorga dzieci: trzech dziewczynek i trzech chłopców. Pierwsza przyszła na świat Eryka (1905), urodzona równo dziewięć miesięcy po ślubie. W dalszej kolejności pojawili się: Klaus (1906), Golo (1909), Monika (1910), Elisabeth (1918) oraz Michael (1919).

${ }^{63}$ I. i W. Jen s, Pani Tomaszowa..., s. 64-65.

${ }^{64} \mathrm{~W}$ akcie własności willi przy Poschingerstraße widniało tylko nazwisko Katii - ibidem, s. 79.

${ }^{65}$ I. i W. Jens, Katias Mutter..., s 112-118.

${ }^{66}$ K. Mann, Moje..., s. 61.

${ }^{67}$ K. Jüngling, B. Roß beck, op. cit., s. 72.

${ }^{68}$ G. Mann, op. cit., s. 20, 212-213.

${ }^{69} \mathrm{~W}$ dziennikach pisarza można znaleźć wzmianki o jego „wizytach” (dosł. rencontre) w sypialni żony. Por. T. Mann, Dzienniki, t. I (Wybór 1918-1921), Poznań 1995, s. 230. 
Zarówno Tomasz, jak i Katia pragnęli być rodzicami. Dla pisarza urodziny pierwszego dziecka były niczym wprowadzenie w „misterium życia”. Zaskoczeniem dlań była także radość $z$ powodu płci niemowlęcia. Wprawdzie przed narodzinami Eryki deklarował, że chciałby mieć syna ${ }^{70}$, ale już w pierwszych dniach życia córki był dumny $z$ powodu zostania ojcem dziewczynki ${ }^{71}$. Podobna radość pisarz przeżył po urodzeniu Elisabeth, a świadectwem entuzjazmu były zapiski $\mathrm{w}$ dziennikach $\mathrm{z}$ lat 1918-192172. Zaskakujaco odmienne preferencje co do płci dzieci miała Katia. We wspomnieniach nie kryła większej radości z powodu narodzin synów, zwłaszcza pierwszego $z$ nich - Klausa ${ }^{73}$.

Wychowaniem dzieci Mannów zajmowała się głównie matka. Tomasz Mann był wprawdzie dla potomstwa „ostatnia instancja”, ale jego rola sprowadzała się do okazjonalnych spacerów, wieczornego czytania książek czy wyjścia do teatru ${ }^{74}$. Mali Mannowie musieli przestrzegać domowej ciszy podczas przedpołudniowych godzin pracy ojca, jak również w czasie jego poobiedniej drzemki ${ }^{75}$. Temperament rozładowywali podczas zabaw $z$ dziećmi sąsiadów, wywodzacymi się jak oni sami $z$ wyższej klasy średniej. W miarę dorastania Eryki i Klausa wręcz „terroryzowali” oni okolicę zachowaniem odbiegającym od manier właściwych ich warstwie społecznej. Ciężar usprawiedliwiania niesfornego potomstwa brała na siebie Katia. Oboje rodzice byli tolerancyjni wobec wybryków dzieci, a pisarz okazywał wręcz dumę $z$ powodu silnych osobowości swych pociech ${ }^{76}$.

Nowoczesnym elementem stylu wychowawczego Mannów był sposób ubierania potomstwa. Stroje miały nie krępować ruchów, być estetyczne i wygodne. Córki pisarza nosiły proste uczesania - bądź w formie warkocza oplecionego wokół głowy (Eryka), bądź w formie półkrótkiej („na pazia”) ${ }^{77}$. W okresie letnim mali Manno-

${ }^{70}$ Deklaracja Manna nie była spontaniczna, stanowiła jedynie reakcję na pytanie Hedwig Dohm. Deklarująca się jako zwolenniczka praw kobiet babka Katii przyjęła odpowiedź pisarza z oburzeniem. Por. K. Man n, Moje..., s. 26-27.

${ }^{71}$ K. Jedynakiewicz-Mróz, Zawsze pod prąd. Życie Eryki Mann (1905-1969), Warszawa 2013, s. 17.

72 T. Mann, Dzienniki..., s. 6, 73, 218, 221.

${ }^{73}$ K. Mann, Moje..., s. 27; K. Man n, Kind..., s. 39-40.

${ }_{74}$ M. Mann, op. cit., s. 18, 24; K. Mann, Kind..., s. 18.

75 G. Mann, op. cit., s. 48.

76 Ibidem.

77 K. Mann, Punkt..., s. 30; G. Mann, op. cit., s. 32. 
wie bardzo często biegali boso ${ }^{78}$. Podobnie jak ich matka uprawiali sporty: pływanie, tenis i narciarstwo. Podkreślaniu indywidualności dzieci służyły własne pokoje, przynajmniej od momentu zamieszkania rodziny w domu przy Poschingerstraße ${ }^{79}$.

Niekonwencjonalny charakter nosiło także zwracanie się do rodziców za pomoca przydomków. Katia określana była mianem Mielein, Tomasz - Pielein lub Zauberer. Imiona dzieci były zdrabniane lub przerabiane na oryginalne formy: Eri (Eryka), Aissi (Klaus), Golo (de facto Angelus), Moni (Monika), Medi (Elisabeth) i Bibi (Michael).

$\mathrm{Na}$ tle rówieśników mali Mannowie czuli się wyróżnieni, co w praktyce przekładało się na poczucie wyjątkowości wobec otoczenia. Egotyczna postawa potomstwa nie była korelowana przez działania rodziców. W istocie rzeczy ani pisarz, ani jego żona nie przejawiali konsekwencji w ocenie zachowań dzieci. Brak klarownych regul przyniesie w okresie dorastania potomstwa Mannów poważne problemy wychowawcze ${ }^{80}$. Wada postępowania Tomasza i Katii było także nierówne traktowanie dzieci. Ulubienicami obojga były Eryka i Elisabeth; Katia wyróżniała ponadto Klausa. Z kolei Golo i Michael dość wcześnie zaczęli odczuwać dyskomfort $z$ powodu chłodu ojca ${ }^{81}$. „Czarna owca” wśród potomstwa Mannów była Monika (arme Mönle), niespełniająca ambicji żadnego $z$ rodziców.

Bezsprzeczną zasługa Tomasza i Katii było pielęgnowanie tradycji rodzinnego obchodzenia urodzin, rocznic i świąt. Najważniejszym wydarzeniem w domu była Wigilia Bożego Narodzenia. Nadzorowaniem świątecznych przygotowań zajmowała się Katia, ale dobór prezentów należał do obojga małżonków. Kolację wigilijna poprzedzał dziecięcy śpiew kolęd oraz zapalenie świeczek na choince. Gościem wieczerzy była Hedwig Pringsheim, natomiast z Alfredem spotykano się na obiedzie pierwszego dnia świąt w domu przy Arcisstrasse ${ }^{82}$.

78 G. Mann, op. cit., s. 47.

79 Warto podkreślić, że w powyższej kwestii mali Mannowie mieli większe przywileje niż dzieci Pringsheimów. W pałacu przy Arcisstraße własnym pokojem dysponowała jedynie Katia, mieszkająca jednak $z$ boną. Jej bracia dzielili drugi z pokojów dziecięcych. Por. K. Jüngling, B. Roß beck, op. cit., s. 35.

${ }^{80}$ Por. K. Mann, Kind..., s. 105-106.

${ }^{81}$ Świadectwem różnego traktowania dzieci sa dzienniki pisarza. Por. M. F1ü gge, Das Jahrhundert..., s. 342-343.

${ }^{82}$ M. Mann, op. cit., s. 24; T. Mann, Dzienniki..., s. 70. 
Wprawdzie ani Tomasz, ani Katia nie byli praktykującymi ewangelikami, ale w stosunku do dzieci dbali o dopełnienie chrześcijańskich ceremonii. Mali Mannowie zostali ochrzczeni już w niemowlęctwie, a w wieku 14-15 lat przystapili do konfirmacji ${ }^{83}$. Wspomniane uroczystości traktowano jednak w domu pisarza bardziej jako tradycje niż podstawę wychowania potomstwa. Wprawdzie przyszły noblista uważał się za człowieka głęboko wierzącego, ale przekonania swe rzadko uzewnętrzniał. Katia była prawdopodobnie agnostyczka, tak jak jej ojciec Alfred Pringsheim.

Kolejne lata małżeństwa Mannów przynosiły stopniowy wzrost pozycji pani domu. Już przed ślubem Katia potrafiła skutecznie przekonywać narzeczonego do stanowczego upominania się o honorarium ${ }^{84}$. Po zamążpójściu szybko nauczyła się zarządzać rodzinnymi finansami, zwłaszcza że Tomasz Mann wykazywał we wspomnianych kwestiach rażący brak talentu. W miarę wzrostu źródeł dochodów męża Katia przejęła stopniowo rolę negocjatorki kontraktów i księgowej czuwającej nad płaceniem podatków ${ }^{85}$. Równolegle troszczyła się o zdrowie męża, już przed ślubem cierpiącego na nawracająca nerwicę wegetatywną ${ }^{86}$.

Aktywność Katii nie sprowadzała się tylko do czynności organizacyjnych. Wprawdzie we wspomnieniach podkreślała, że nigdy nie wtrącała się w projekty literackie męża, ale on sam nierzadko zwracał się do niej z prośbą o radę. Katia była nie tylko pierwszą słuchaczka prac pisarza, lecz także dostarczycielką wątków narracyjnych. Największa rolę odegrała w powstaniu powieści $\mathrm{Cza}$ rodziejska góra, opartej częściowo na osobistych obserwacjach pacjentów sanatorium w Davos ${ }^{87}$. Na kanwie intymnych rozmów z żona Tomasz Mann napisał również nowelę Oszukana. Utwór przedstawiał historię kobiety w okresie klimakterium, której objawy powrotu „kobiecości” okazują się symptomem choroby nowotworowej ${ }^{88}$.

${ }^{83}$ T. Mann, Dzienniki..., s. 30, 246-247.

${ }^{84}$ K. Mann, Moje..., s. 25-26.

85 T. Mann, Dzienniki..., s. 36-37, 179; K. Mann, „Liebes...”, s. 106-107; K. Mann, Moje..., s. 36.

${ }^{86}$ M. Mann, op. cit., s. 30; K. Mann, Moje..., s. 142.

${ }^{87}$ K. Mann, Moje..., s. 70-71. Katia Mann przebywała w Davos dwukrotnie - w 1912 i 1924 r. Podczas pierwszego pobytu spędziła w sanatorium siedem miesięcy. Tomasz Mann towarzyszył wówczas żonie przez miesiąc.

${ }^{88}$ Ibidem, s. 81-82. 
Wraz z coraz liczniejszymi odczytami i rosnaçą korespondencją pisarza Katia przyjęła na siebie funkcję jego nieformalnej sekretarki. To jej dyktował listy, polityczne deklaracje i teksty prelekcji ${ }^{89}$. W odróżnieniu od męża, niechętnego nowinkom technicznym, szybko nauczyła się pisać na maszynie, a w roku 1925 zdała egzamin na prawo jazdy. Wprawdzie przyszłego noblistę stać było na zatrudnienie szofera, ale to Katia stała się z czasem głównym kierowca męża. Jej styl prowadzenia auta był nonszalancki - często przekraczała dozwoloną prędkość i parkowała w niedozwolonych miejscach ${ }^{90}$.

W pierwszych kilkunastu latach małżeństwa zdrowie żony pisarza budziło niepokój lekarzy. Powinności domowe wyczerpywały nienawykłą wcześniej do licznych obowiązków Katię. Z uwagi na nawracające infekcje dróg oddechowych oraz utrzymujacy się stan podgoraczkowy w 1912 r. żona Tomasza Manna poddała się badaniu płuc. Lekarz zdiagnozował zamknięta gruźlicę i zalecił kurację sanatoryjna. Jeszcze w tym samym roku Katia spędziła siedem miesięcy w Davos, a w latach 1913-1914 kolejne miesiące w Meranie i Arosie. Po urodzeniu Elisabeth i Michaela kontynuowała leczenie w formie kilkutygodniowych pobytow sanatoryjnych. Jej ostatnia kuracja miała miejsce wiosna 1926 r. ${ }^{91}$ Mimo dalszych wahań temperatury ciała pacjentka zrezygnowała wówczas $z$ dalszego leczenia. Po latach bagatelizowała swój ówczesny stan, podkreślając, że późniejsza analiza dokumentacji choroby nie potwierdziła diagnozy z roku 1912 ${ }^{92}$. Opuszczając w 1926 r. sanatorium, żyła jeszcze ponad pół wieku, dożywając 97 lat.

Niektórzy biografowie Katii sugeruja psychologiczne tło jej dolegliwości zdrowotnych. Wspomniana hipoteza ma związek $z$ problemem radzenia sobie $z$ homoerotycznymi skłonnościami męża ${ }^{93}$. Nie wiemy, kiedy poznała tę stronę osobowości Tomasza Manna. Prawdopodobnie stało się to podczas wspólnego wypoczynku pary na Lido w czerwcu 1911 r. Autor Buddenbrooków przeżył wówczas platoniczna fascynację polskim chłopcem, przebywającym $z$ rodziną w weneckim kurorcie ${ }^{94}$.

\footnotetext{
89 T. Mann, Dzienniki..., s. 89.

90 Die Briefe..., s. 57.

91 Por. K. Mann, „Liebes...”, s. 114.

${ }^{92}$ K. Mann, Moje..., s. 70.

${ }_{93}$ K. Jüngling, B. Roß ß e ck, op. cit., s. 104.

${ }^{94}$ K. Mann, Moje..., s. 63 i n. Namacalnym potwierdzeniem uczuć Tomasza Manna była powieść Śmierć $w$ Wenecji.
} 
Należy przypuszczać, że postawa pisarza nie była dla Katii zjawiskiem nieznanym. Podobne upodobania przejawiał również jej brat Klaus, w życiu realnym mąż i ojciec ${ }^{95}$. Zachowanie męża odbierała zapewne jako dysonans, ale czy wspomniana ocena pociagnęła za soba „ucieczkę w chorobę"? Realnym powodem poczattku problemów zdrowotnych było raczej przemęczenie kolejnymi porodami (1909, 1910) oraz dwoma poronieniami (1911, 1913). Prawdopodobnie jak jej matka nauczyła się racjonalizować skłonności męża, zwłaszcza że nie pociagały one za sobą fizycznej zdrady.

Istotny wpływ na poprawę samooceny Katii miała rola odegrana przez nią w małżeństwie w latach 1914-1918. Wprawdzie Tomasz Mann nie został powołany do wojska, ale $z$ uwagi na jego brak talentu organizacyjnego obowiązek zaopatrzenia rodziny spoczął na jego żonie. Skala osiagnięć Katii w pozyskiwaniu pozakartkowej żywności i opału przekroczyła oczekiwania jej najbliższych. Golo Mann wspominał później, że jego matka stała się w czasie wojny „rodzajem bohaterki”, chroniącej męża i dzieci przed przeciwnościami losu ${ }^{96}$. Jej rowerowe, także zima, eskapady i kontakty z ludźmi ocierającymi się o półświatek stały się powodem głębokiej wdzięczności Tomasza Manna ${ }^{97}$.

Umocnienie podstaw małżeństwa Mannów przyniosła pierwsza połowa lat dwudziestych, naznaczona coraz większą renomą pisarza oraz wzrostem pozycji jego żony. Symptomem wzrostu poczucia wartości obojga było rozluźnienie więzi z Pringsheimami, szczególnie widoczne w przypadku Katii. Ta ostatnia ostatecznie „wyzwoliła się" spod wpływu matki, silnego zwłaszcza w pierwszych latach małżeństwa ${ }^{98}$. Po wyjściu $z$ okresu dzieciństwa Elisabeth i Michaela Katia zaczęła odgrywać rolę nie tylko powiernicy męża, lecz także towarzyszki jego odczytów i spotkań autorskich. Ukoronowaniem tej roli stało się uczestnictwo w ceremonii przyznania pisarzowi literackiej Nagrody Nobla w 1929 r. w Sztokholmie.

\footnotetext{
95 K. Jüngling, B. Roß beck, op. cit., s. 53.

96 G. Mann, op. cit., s. 36 i n.

97 M. Mann, op. cit., s. 16; K. Mann, Punkt..., s. 58-59.

98 I. i W. Jen s, Katias Mutter..., s. 156-157.
} 


\section{Charakter relacji małżeńskich Tomasza i Katii Mannów}

Zarówno Tomasz, jak Katia byli silnymi osobowościami już w momencie wejścia w związek małżeński. On był człowiekiem introwertycznym, pochłoniętym pracą literacka, ważącym słowa, skupionym na sobie, choć niestroniącym od świata. Ona teoretycznie stanowiła jego zaprzeczenie - logiczna i pragmatyczna, szybka w mowie, obcesowa w sądach, nieco roztrzepana, często robiąca kilka rzeczy jednocześnie ${ }^{99}$.

Analiza osobowości Tomasza i Katii Mannów pozwala dostrzec niewidzialne na pierwszy rzut oka zbieżności charakterologiczne tej pary. Oboje byli miłośnikami muzyki klasycznej, teatru i literatury. Elementem łączącym były także zbliżone poglądy polityczne, ewoluujace pod wpływem wydarzeń w Niemczech od konserwatyzmu do lewicowego liberalizmu.

Mimo dystansu wobec haseł emancypacji Tomasz Mann odbiegał zarówno od stereotypów antyfeminizmu, jak i częstego w rodzinach mieszczańskich wzorca patriarchalnego. Od początku szanował potrzeby żony, starając się zaspokajać także jej aspiracje intelektualne ${ }^{100}$. We wszystkich miejscach zamieszkania Mannów Katia miała własny pokój, będący połączeniem sypialni, buduaru i gabinetu ${ }^{101}$. Dowód troski autora Czarodziejskiej góry o zdrowie żony stanowiły zapiski w jego dziennikach ${ }^{102}$. Gdy w 1919 r. lekarze rozważali zabieg aborcji u osłabionej fizycznie Katii, pisarz wspierał ja niezależnie od rodzaju decyzji, jaka gotowa była podjąć ci3 $^{103}$

99 T. Mann, Dzienniki..., s. 157; M. Mann, op. cit., s. 10. Obcesowość i brak konsekwencji owocowały m.in. ciagłymi problemami Katii ze służbą. Por. K. M a n n, Punkt..., s. 70-73.

100 Gdy Hedwig Pringsheim zwróciła uwage zięcia na „znudzenie” Katii obowiązkami pani domu, Tomasz Mann próbował załatwić dla żony kontrakt na tłumaczenie na niemiecki jednego $z$ dzieł Gustawa Flauberta. W latach dwudziestych, dzięki kontaktom pisarza, Katia przetłumaczyła powieść Williama Makepeace'a Thackereya Targowisko próżności. Tłumaczenie ukazało się drukiem w 1950 r. w Niemieckiej Republice Demokratycznej. Por. K. Jüngling, B. Roßbeck, op. cit., s. 90, 305.

101 M. Man n, op. cit., s. 12-13.

102 Dzienniki Tomasza Manna zaskakuja dobra orientacja pisarza w sprawach intymnego zdrowia żony. Autor Czarodziejskiej góry znał m.in. szczegóły jej dolegliwości ginekologicznych w okresie klimakterium. Por. T. Mann, Dzienniki..., s. 171 .

103 Ibidem, s. 15-17. 
Tak jak Tomasz Mann odbiegał od modelu patriarchalnego pana domu, tak Katia nie przypominała swym stylem życia wzorca „kobiety wyzwolonej”. Mimo wykształcenia i licznych zainteresowań nie odczuwała potrzeby budowania swej tożsamości, bazując na pracy zawodowej. W życiu codziennym podkreślała przede wszystkim rolę żony, np. przez podpisywanie listów formuła „Pani Tomaszowa Mann”104. Już w latach dwudziestych negatywnie oceniała zachowanie partnerek życia znanych pisarzy, próbujących publicznie dyskontować zasługi swych małżonków ${ }^{105}$.

Wspomniane poglądy Katii nie oznaczały jednak braku poczucia własnej odrębności. W miarę dojrzewania w roli żony wypracowała sobie autonomiczna pozycję w związku. Mimo podkreślenia braku zasług własnych nie traktowała oddania mężowi i dzieciom jako „ofiary”, lecz w kategoriach „oddania” i „służby”106.

Choć zarówno Tomasz, jak Katia podjęli decyzję o małżeństwie $z$ racjonalnych i trzeźwo wykoncypowanych powodów, w ich związku nie brakowało ciepła i czułości. O tych ostatnich świadczyły wzajemne przydomki, stosowane w życiu codziennym. Ona nazywała męża „sarną" i „owieczką”, on używał określenia „Kasieńka” (Katiulein) lub „zajęczyca” (die Häsin) ${ }^{107}$. Wprawdzie - jak większość mężczyzn swej epoki - pisarz nie deklarował często uczuć wobec żony, ale w dziennikach zdarzało mu się podkreślać głęboką więź $z$ tą ostatnią ${ }^{108}$. Oboje przedkładali własne towarzystwo nad kontakty $z$ osobami postronnymi ${ }^{109}$. W pierwszej kolejności łączyła ich wspólnota zainteresowań i podobne oceny świata. Zdecydowanie rzadziej dawali się ponosić emocjom, kontrolowanym ryzami dobrych manier.

$$
* * *
$$

Małżeństwo Tomasza i Katii Mann było jednym z wielu związków małżeńskich zawieranych w początkach XX w. przez przedstawicieli niemieckiej bohemy artystycznej. Inaczej niż w przypadku swe-

104 Por. K. Mann, „Liebes...”, s. 17.

105 I. i W. J en s, Pani Tomaszowa..., s. 123. Skromność Katii nie dotyczyła jednak sytuacji prozaicznych. Powołując się na nazwisko męża, potrafiła upominać się o lepszy pokój w hotelu. Por. K. Ma n n, „Liebes...”, s. 101.

${ }^{106} \mathrm{~W}$ języku niemieckim określenia te mają bardziej wyrazista konotację znaczeniowa („sich opfern” contra „sich widmen”). Por. ibidem, s. 21.

107 Ibidem, s. 32.

108 Por. T. Mann, Dzienniki..., s. 162-163.

109 Ibidem, s. 105. 
go brata, Henryka Manna, autor Buddenbrooków już w momencie ślubu był tylko powierzchownie związany $z$ monachijska cyganeria epoki fin de siècle' $u^{110}$. W momencie starań o rękę panny Pringsheim przyszły noblista miał już za soba nieład uczuciowy i nonszalanckie traktowanie norm moralnych. Także wybranka pisarza bez żalu rozstawała się $z$ wzorcami emancypacji kobiet początków nowego stulecia.

Mimo świadomego wyboru mieszczańskiego stylu życia przez oboje, małżeństwo Mannów odbiegać miało od tradycyjnych wzorców. Źródłem inności były nie tylko złożona osobowość autora Czarodziejskiej góry, lecz także wyraziste cechy charakteru jego żony. Choć w zakończeniu wspomnień stwierdzała, że „nigdy nie mogła robić tego, czego chciała" ${ }^{111}$, to konkluzja ta stanowiła przekorne zaprzeczenie dokonanego w książce bilansu życia. W istocie rzeczy była przez 50 lat współtwórczynią mitu rodziny Mannów.

\section{Bibliografia}

\section{Ź RÓDEA DRUKOWANE}

Die Briefe der Manns. Ein Familienporträt, hrsg. T. Lahme, H. Pils, K. Klein, Frankfurt am Main 2016.

Mann G., Erinnerungen und Gedanken. Eine Jugend in Deutschland, Frankfurt am Main 1986.

Mann K.[atia], „Liebes Rehherz”. Briefe an Thomas Mann 1920-1950, hrsg. I. Jens, D. Heißerer, 2. Ausgabe, Würzburg 2016.

Mann K.[atia], Moje nienapisane wspomnienia, Warszawa 2007.

Mann K.[laus], Kind dieser Zeit, Reinbek bei Hamburg 1993.

Mann K.[laus], Punkt zwrotny, Warszawa 1993.

Mann M., Vergangenes und Gegenwärtiges, Erinnerungen, Reinbek bei Hamburg 2001.

Mann T., Dzienniki, t. I (Wybór 1918-1921), Poznań 1995.

\section{OpRacowania}

Breloer H., Unterwegs zur Familie Mann. Begegnungen, Gespräche, Interviews, Frankfurt am Main 2001.

Flügge M., Das Jahrhundert der Manns, Berlin 2015.

110 Małżeństwo Henryka Manna z aktorką Mimi Kaanovą wpisywało się w praktykę związków nawiązywanych w obrębie środowiska artystycznego. Więcej na ten temat: M. F1ügge, Heinrich Mann, s. 145-153.

${ }^{111}$ K. Mann, Moje..., s. 146. 
Flügge M., Heinrich Mann. Eine Biographie, Frankfurt am Main 2006.

Jedynakiewicz-Mróz K., Zawsze pod prąd. Życie Eryki Mann (1905-1969), Warszawa 2013.

Jens I., Jens W., Katias Mutter. Das außerordentliche Leben der Hedwig Pringsheim, Reinbek bei Hamburg 2007.

Jens I., Jens W., Pani Tomaszowa Mann, Warszawa 2006.

Jüngling K., Roßbeck B., Katia Mann. Die Frau des Zauberers. Biografie, München 2003.

Krühl M., Im Netz der Zauberer. Eine andere Geschichte der Familie Mann, Frankfurt am Main 1993.

Kurzke H., Tomasz Mann. Życie jako dzieło sztuki, Warszawa 2005.

Lahme T., Die Manns. Geschichte einer Familie, Frankfurt am Main 2015.

Reich-Ranicki M., Thomas Mann und die Seinen, Frankfurt am Main 1990.

KatARZyna JedynAKIEWICZ-MróZ

UNIVERSITY OF LODZ

\section{Between the convention and modernity - from the history of the marriage of Thomas and Katia Manns}

$\mathrm{T}_{\mathrm{h}}^{\mathrm{h}}$

he article presents original (against a background of the era) character of the marriage of Thomas and Katia Mann. Basing on the memoires and the correspondence of writer's family members, there are shown the conventional and modern elements of their marital union, in the context of the personal relations, as well as from the perspective of the progeny upbringing model. The structure of the article has got the chronological and problem character.

In the first part of the deliberations there is presented the youthful experiences of Thomas Mann and Katia Pringsheim, up to the moment of their entering into marriage (1904). In the second there is analysed the process of the forming of the marital and parental relations of the Manns (1904-1914). The third part of the text presents the evolution of the position of Katia Mann in the couple (1914-1919). In the last part of the article there is done the overall analysis of the character of Thomas and Katia Mann's marital relations, with the emphasizing of the traditional and the unconventional characteristics of their marriage.

Keywords: the Mann family, Thomas Mann, Katia Mann, marriage in Germany in the $20^{\text {th }}$ century. 